\section{Scientific journal}

PHYSICAL AND MATHEMATICAL EDUCATION

Has been issued since 2013 .

Науковий журнал

ФІЗИКО-МАТЕМАТИЧНА ОСВІТА

Видається з 2013.
ISSN 2413-158X (online)

ISSN 2413-1571 (print)

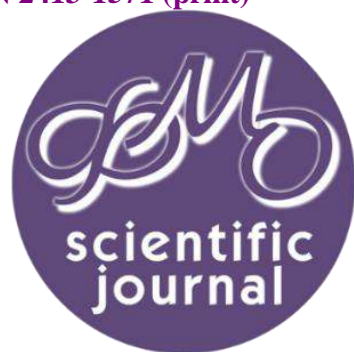

Майкл Г. Воскоглу. Способи мислення при вирішенні проблем. Фізико-математична освіта. 2020. Випуск 3(25).

Частина 1. С. 11-18.

Voskoglou Michael Gr. Modes Of Thinking In Problem Solving. Physical and Mathematical Education. 2020. Issue 3(25). Part 1. P. 11-18.

DOI 10.31110/2413-1571-2020-025-3-002

Michael Gr. Voskoglou

Graduate Technological Educational Institute of Western Greece, Patras, Greece voskoglou@teiwest.gr; mvoskoglou@gmail.com

\title{
MODES OF THINKING IN PROBLEM SOLVING
}

\section{ABSTRACT}

Formulation of the problem: Problem Solving affects our daily lives in a direct or indirect way for centuries. Volumes of research have been written about it and attempts have been made by scientists to make it accessible to all in various degrees. The modes of thinking used in Problem Solving is, therefore, a very interesting and timely subject to study. The present paper discusses the main modes of thinking involved in PS, which are Critical Thinking (CrT), Computational Thinking (CT) and Statistical Thinking (ST). Emphasis is given to ST and in particular to Bayesian Reasoning due to its great importance for everyday life and science that only recently has been fully recognized. We start with a brief description of the use of CrT in PS. Next ST and the necessity of combining it with $\mathrm{CrT}$ in PS is discussed, while Bayesian reasoning is studied separately afterwards. Next the role of CT for solving complex technological problems is examined and the paper closes with the final conclusion.

Materials and methods. The methods of analysis used are based on a synthesis of already reported researches and on suitable examples illustrating our results.

Results. The article studies the role of Statistical Thinking in Problem Solving, where the problem is considered with its wide meaning (not mathematical problems only). Particular emphasis is given to Bayesian Reasoning, whose importance in everyday life and science applications has been only recently fully recognized. Critical and Computational Thinking, the other two main modes of thinking used in Problem Solving, are also discussed

Conclusions. Problem Solving is a complex cognitive process that needs the combination of several modes of thinking in order to be successful. Those modes, apart from the simple spontaneous thinking, include Critical, Statistical and Computational Thinking.

KEY WORDS: Problem Solving (PS), Critical Thinking (CrT), Statistical Thinking (ST), Computational Thinking (CT), Bayesian Reasoning, Fuzzy $\operatorname{Logic}(F L)$.

\section{INTRODUCTION}

In this work the concept of problem is considered with its wide meaning (not mathematical problems only). According to Schoenfeld [1] a "problem" is only a problem, if you don't know how to go about solving it. A "problem" that has no surprises in store, and can be solved comfortably by routine or familiar procedures (no matter how difficult!) is not actually a problem, it is an exercise.

The importance of Problem Solving (PS) has been realized for such a long time that in a direct or indirect way affects our daily lives for centuries. Volumes of research have been written for PS and attempts have been made by many educators, psychologists, philosophers and other special scientists to make it accessible to all in various degrees. However, even graduates have nowadays difficulty in solving real life problems. Somehow, they cannot apply theory into practice, or theorize/reflect on practice. In fact, it is the human mind in the end that has to be applied in a problematic situation and solve the problem.

PS is a complex phenomenon and no wonder there is no unique definition about it. In this work PS is understood to be the activity that makes use of cognitive and physical means to overcome an obstacle and develop a better idea of the world that surrounds us. This definition encompass most of the existing in the literature definitions about PS ([2-4], etc.).

The capacity to solve problems is directly related to the knowledge stored in an individual's mind, and knowledge is a product of thinking. The nature of the problem dictates the level of thinking. But thinking can vary from a very simple and mundane thought to a very sophisticated and complex one. The lower-order thinking requires minimum cognitive effort and it is algorithmic. On the contrary, the higher-order thinking is a complex mode of thinking facilitating the transfer of knowledge, i.e. the use and transformation of already existing knowledge in creating new knowledge.

The present paper discusses the main modes of thinking involved in PS, which are Critical Thinking (CrT), Computational Thinking (CT) and Statistical Thinking (ST). Emphasis is given to ST and in particular to Bayesian Reasoning due to its great 
importance for everyday life and science that only recently has been fully recognized. We start with a brief description of the use of CrT in PS. Next ST and the necessity of combining it with CrT in PS is discussed, while Bayesian reasoning is studied separately afterwards. Next the role of CT for solving complex technological problems is examined and the paper closes with the final conclusion.

\section{RESULTS AND DISCUSSION}

\section{Critical Thinking in Problem Solving}

$\mathrm{CrT}$ is the intellectual process of conceptualizing, applying, analyzing, synthesizing and evaluating information gathered from observation, experience, reflection, reasoning, or communication. It has its roots in the ancient Greek philosopher Socrates (470-399 BC), who perfected the art of questioning by asking pertinent questions to show that people could not rationally justify their confident claims of knowledge. An example of the Socrates' technique will be presented in the next section.

$\mathrm{CrT}$ is a complex mode of thinking that often generates multiple solutions. Through it thinking skills of higher level such as analysis, synthesis and evaluation are combined giving rise to other skills like inferring, estimating, predicting, generalising, and creative thinking. Halpern's [5] approach of thinking as information processing is complemented by McGuinness's [6] view of thinking as making judgements. And making judgements is directly related to $\mathrm{CrT}$.

The complexity of $\mathrm{CrT}$ becomes evident by the fact that, although many definitions can be found in the literature about it, no one of them is universally accepted. A combination of the definitions by Halpern [5] and Williams [7] give rise to the following working, for the present study, definition: " $\mathrm{CrT}$ is the ability by which the individual transcends his/her subjective self in a wilful manner in order to arrive rationally at conclusions that can be substantiated using valid information".

CrT affects acquisition of knowledge, as knowledge is the product of thinking about concepts and combining them with principles. Concepts are acquired through abstractions and principles connect the concepts thus forming a network. Any new concept encountered has to fit in the existing cognitive structure. Such accommodation would not be possible without CrT. When a problem is encountered, before being solved it has to be analysed in a critical way: What is the problem, what is the given information and so on. Therefore, $\mathrm{CrT}$ is also involved in application of knowledge to solve the problem. In conclusion, $\mathrm{CrT}$ is a prerequisite to knowledge acquisition and PS.

The importance of $\mathrm{CrT}$ is one of the seven educational critical outcomes together with PS and many authors support this ([7-11], etc.). With the explosion of information technology and moving away from an industrial society to a knowledge society, the attitude or disposition to think critically is as important as other skills such as professional acquisition of knowledge and lifelong learning $[5,11,12]$. Understanding what $\mathrm{CrT}$ is and how it can be acquired might help the experts on learning to become more effective and efficient in instilling such skills to the learner.

\section{Statistical Thinking}

\section{Probability, Statistics and Fuzzy Logic}

In this work the term ST is understood to be the ability of using principles of Probability and Statistics for solving problems connected to everyday life, science and technology applications. Probability and Statistics are related areas of mathematics, having however fundamental differences. Probability is a theoretical branch of mathematics which deals with predicting the likelihood of future events. On the contrary, Statistics is an applied branch of mathematics, which tries to make sense of observations in the real world by analyzing the frequency of past events.

The distinction between Probability and Statistics could be clarified better by tracing the thoughts of a gambler mathematician during a game with dice. If the gambler is a probabilist, he will think that each face of the dice comes up with probability $\frac{1}{6}$. If instead he is a statistician, he will think: "How I know that the dice are not loaded? I keep track how often each number comes up and once I am confident that the dice are fair I'll decide how to play". In other words, Probability enables one to predict the consequences of an ideal world, whereas Statistics enables him/her to measure the extent to which our world is ideal.

Edwin T. Jaynes (1922-1998), Professor of Physics at the University of Washington, was the first who argued that Probability theory could be considered as a multi-valued generalization of the bivalent logic reducing to it in the special case where our hypothesis is either absolutely true or absolutely false [13]. Many eminent scientists have been inspired by the ideas of Jaynes, like the expert in Algebraic Geometry David Mumford, who believes that Probability and Statistics are emerging as a better way for building scientific models [14].

Nevertheless, both Probability and Statistics have been developed on the basis of the bivalent logic. As a result, they are tackling effectively only the cases of the existing in real world uncertainty which are due to randomness and not those due to imprecision. In cases of imprecision, the Zadeh's Fuzzy Logic (FL) comes to bridge the existing gap [15]. It is recalled that $\mathrm{FL}$ is an infinite-valued on the real interval [0, 1] logic, which is based on the concept of Fuzzy Set (FS) introduced by Zadeh in 1965 [16]. $\mathrm{FL}$, which has found nowadays applications to almost all sectors of the human activity, does not contradict the Aristotle's bivalent logic, but it actually generalizes and completes it. For more details about the basics of FS and FL the reader may look at [17], Section 2.

\section{The Aristotle's Statistical Fallacies}

Fallacies are logically false statements which are often considered to be true. A great number of fallacies are known nowadays (e.g. see [18]), but the first fallacies appeared in the literature simultaneously to the generation of the Aristotle's (384$322 \mathrm{BC}$ ) bivalent Logic. In the "Sophistical Refutations", the last of his six works on logic, Aristotle identified thirteen fallacies and divided them in two categories, the linguistic and non-linguistic ones [19]. The amazing thing, however, which reveals more emphatically the great wisdom of the man, is that, although Statistics was a completely unknown subject on that time, two of the Aristotle's fallacies can be characterized in today terms as statistical fallacies! Those fallacies are the unqualified and the 
hasty generalizations respectively. In the first one a general rule is used to explain a specific case that does not fall under this rule, whereas in the second one it is assumed that something is true in general, because it happens to be true in certain cases.

Assume, for example, that a high school employs 100 in total teachers. Three of them are not good, whereas the other 97 are good teachers. Parent A happens to know only the three not good teachers. Based on it, he concludes that the school is not good and he decides to choose another school for his child. On the contrary, parent B, who knows the 97 good teachers, concludes that the school is good and decides to choose it for his child. In that case, parent A fell into the fallacy of hasty generalizations, whereas parent $B$ fell into the fallacy of unqualified generalizations. It becomes evident, however, that the gravity of consequences of those two fallacies is not the same. In fact, the decision of parent A could jeopardize the future of his child, since the degree of truth of his fallacy is only 3\%.On the contrary, the decision of parent B could possibly benefit his child, since the degree of truth of his fallacy(?) is $97 \%$.

\section{Combining Statistical and Critical Thinking in Problem Solving}

The cultivation of the statistcal literacy is very important, but alone is not enough; it must be combined with CrT. Socrates in his dialogue with his friend Euthydemus - written by his student Plato in 384 BC, i.e. the year of the Aristotle's birth - exploited tacitly the Aristotle's two statistical fallacies to give the following example concerning the importance of CtT for PS in general and decision-making in particular.

Socrates asked Euthydemus, if he thinks that stealing is an immoral action. Of course it is, answered Euthydemus. But what happens, replied Socrates, if your friend wants to commit a suicide and you steal his knife, is this immoral?. No, said the embarassed Euthydemus. Here Euthydemus followed the statistical way of thinking, since in most cases stealing is considered to be an immoral action. Socrates, however, using the above dialogue, taught him that he must combine ST with CrT.

Let us now transfer the dialogue of Socrates with Euthydemus to the previous example with the two parents. Imagine that Socrates (if he was alive on that time) met parent B downtown and asked him: If your child has a particular interest about the lessons taught by the three not good teachers and he is not interested about the lessons taught by the 97 good teachers, is your decision to choose this school right for his future?. After this, parent B became puzzled and he thought that he should reconsider his decision after discussing it with his child.

Apart from the Aristotle's, many other statistical fallacies are known today, such as the sampling bias, the data dreadging, the survivorship bias, the cherry picking, the gambler's fallacy, the regression toward the mean, the thought-terminating cliché, etc. [20]. Many of those fallacies involve lack of CrT as well.

Another characteristic example related to lack of ST and CrT in PS is the Wason's four card problem: A set of four cards is placed on a table, each of which has a number on the one side and a colored patch on the other side. The visible faces of the cards show 3,8, red and brown respectively (Figure 1). Which cards must be turned over in order to test the truth of the proposition that if a card shows an even number, then its opposite face is red? Since only the cards with number 8 and and the red-colored one could contradict the truth of the given proposition, the correct solution is to turn over those two cards. In the Wason's study not even $10 \%$ found the correct solution [21, 22].

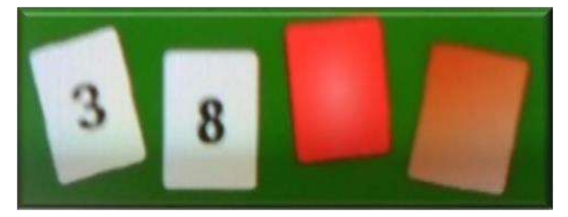

Figure 1. The Wason's four card problem

The famous Linda's problem [23], a special case of the conjunction fallacy, is also related to lack of ST: Linda is 31 years old, single, outspoken and very bright. She majored in Philosophy. As a student, she was deeply concerned with issues of discrimination and social justice, and also participated in anti-nuclear demonstrations. The subjects were asked to choose which one among five given alternatives is the most probable about Linda. Two of those stated that "Linda is a bank teller "and that "Linda is a bank teller and also is active in the feminist movement". The majority of the subjects chose the second statement as more probable than the first one. This violates the law that the probability of a conjunction must be less (or equal) than the probability of its conjuncts.

One could give several explanations about the "irrationality" of the human plausible reasoning.in this case. One of them is that, since Linda majored in Philosophy and was deeply concerned with issues of discrimination and social justice, it looks more probable to be active in the feminist movement than to be a bank teller. In other words, it could be considered that in this case the conjunction was interpreted as disjunction. In fact, as Gould notes ([24], p.469), it seems that our minds are not built to work always by the rules of probability. Aristidou [25] argues that, since the given Linda's description contains many fuzzy characteristics, this "irrationality" could be explained better by using a fuzzy instead of probabilistic model.

\section{Bayesian Reasoning}

The Bayes' Rule of calculating the value of conditional probabilities, which first appeared in the work "An Essay towards a Problem in the Doctrine of Chances", published by Richard Price in 1763, two years after the Bayes' (1701-1761) death, was another important step in the development of probability theory. Laplace (1749-1827), independently from Bayes, pioneered and popularized the conditional probabilities. It must be mentioned, however, that the Bayesian approach used to be for years the reason of a continuous dispute, mainly on philosophical level, between the supporters of it and the supporters of the Laplace's "classical" approach of probability.

A fundamental difference was, for example, that the Laplace's supporters believed that the probabilities exist only for events that have not happened yet, whereas, according to the Bayesian approach, this is not a necessary condition. To make it 
clear, assume that one throws a weighted coin, covers it with his hand and then bets if the indication was "head" or "letters". According to the Bayesian approach, the probability of appearance of each indication is 50\%, whereas according to the classical approach such a probability does not exist, since the event has already happened! It is only recently that the "opponents" of this cognitive fight have been convinced that the two views could exist together and they are equally useful for the scientific progress. Let $A$ and $B$ be two intersecting events. Then it is straightforward to check [26] that the conditional probability for the event $A$ to happen when the event $B$ has already happened is calculated by

$$
\mathrm{P}(\mathrm{A} / \mathrm{B})=\frac{\mathrm{P}(\mathrm{A} \cap \mathrm{B})}{\mathrm{P}(\mathrm{B})} \text {. }
$$

In the same way one finds that

$$
\mathrm{P}(\mathrm{B} / \mathrm{A})=\frac{\mathrm{P}(\mathrm{A} \cap \mathrm{B})}{\mathrm{P}(\mathrm{A})} \text {, or } \mathrm{P}(\mathrm{A} \cap \mathrm{B})=\mathrm{P}(\mathrm{B} / \mathrm{A}) \mathrm{P}(\mathrm{A}) \text {. }
$$

Therefore (1) can be written in the form

$$
\mathrm{P}(\mathrm{A} / \mathrm{B})=\frac{\mathrm{P}(\mathrm{B} / \mathrm{A}) \mathrm{P}(\mathrm{A})}{\mathrm{P}(\mathrm{B})} \text {. }
$$

Equation (2), which calculates the conditional probability $P(A / B)$ with the help of the inverse in time conditional probability $\mathrm{P}(\mathrm{B} / \mathrm{A})$, the prior probability $\mathrm{P}(\mathrm{A})$ and the posterior probability $\mathrm{P}(\mathrm{B})$, is known as the Bayes' rule. In other words, the Bayes' rule calculates the probability of an event based on prior knowledge of conditions related to that event. When applied in practice, the Bayes' rule may have several interpretations. In social sciences, for example, it describes how a degree of belief expressed as a probability $\mathrm{P}(\mathrm{A})$ is rationally changed according to the availability of related evidence. In that case, the probabilities involved in the Bayes' theorem are frequently referred as Bayesian probabilities, although, mathematically speaking, Bayesian and conditional probabilities are actually the same thing.

The value of the prior probability $\mathrm{P}(\mathrm{A})$ is fixed before the experiment, whereas the value of the posterior probability is calculated with the help of the experiment's data. Usually, however, there exists an uncertainty about the exact value of $P(A)$. In such cases, considering all the possible values of $\mathrm{P}(\mathrm{A})$, we obtain through the Bayes' rule different values for the conditional probability $\mathrm{P}(\mathrm{A} / \mathrm{B})$. Therefore, the Bayes' rule, unlikely to the classical probability theory, introduces a kind of multi-valued logic tackling the existing, due to the imprecision of the value of the prior probability uncertainty in a way analogous to FL! Consequently, one could argue that Bayesian reasoning constitutes an interface between bivalent and FL.

Although the Bayes' rule is a straightforward consequence of equation (1) calculating the value of a conditional probability, Bayesian reasoning has been proved to be very important in everyday life and science [27-29]. Recent researches give also evidence that most of the mechanisms under which the human brain works are Bayesian [28]. Consequently, Bayesian reasoning becomes very useful for Artificial Intelligence (AI), which focuses on the design and construction of machines that mimic the human behavior. In fact, the smart machines of Al are supplied with Bayesian algorithms in order to be able to recognize the corresponding structures and to make autonomous decisions.

The physicist and Nobel Prize winner John Mather expressed his uneasiness about the possibility that the Bayesian machines could become too smart in future, so that to make humans to look useless [30]! Consequently, Sir Harold Jeffreys (1891-1989), a British mathematician who introduced the concept of the Bayesian algorithm and played an important role in the revival of the Bayesian view of probability, had successfully characterized the Bayesian rule as the "Pythagorean Theorem of Probability Theory" [31].

\section{Bayesian Reasoning in Everyday Life}

The Bayes rule has been proved a very useful tool for solving problems appearing in everyday life situations. A characteristic example is connected to the Aristotle's fallacy of false inversion, according to which the proposition "If A then B" implies always the inverse proposition "If $B$ then $A$ " [19]. That fallacy belongs to the category of fallacies of cause and effect, where $A=$ the cause and $B=$ the effect and where the cause always precedes chronically the effect.

Assume, for example, that in a farm live 100 in total animals, 75 of them having 4 feet (e.g. cats, dogs, goats, cows and horses) including 3 cats and the rest of them having 2 feet (e.g. chicken). Consider the propostion "The cats are animals having 4 feet". Find the degree of truth of the inverse proposi tion "An animal living in this farm has 4 feets, therefore is a cat".

Here we have that $A=$ cats and $B=$ animals having 4 feet, therefore $P(B / A)=1$. Consequently, equation (2) gives that $P(A / B)=\frac{P(A)}{P(B)}$. But $P(A)=\frac{3}{100}, P(B)=\frac{75}{100}$, therefore $P(A / B)=\frac{3}{75}=0.04$. Hence the degree of truth of the false inversion in this case is only $4 \%$.

Nevertheless, the conditional probability $P(B / A)$ is not always equal to 1 , as it happens, for example, if $A=I$ have flu and $B=$ I feel pain in my throat. It is of worth noting that the only information given within the premises of bivalent logic about this fallacy is that the inversion between cause and effect is false in general, or otherwise that the conditional probability $P(A / B)$ is not always equal to 1 . However, this information is useless in practice, where one wants to know "what is" (via positiva) and not "what is not" (via negativa). The latter, for example, is a method that has been followed by the religion when failed to define "what is the God". It was decided then to define instead "what is not the God" (Cataphatic and Apophatic Theologies), which is much easier to be done.

Bayesian reasoning is frequently used in medical applications the outcomes of which are not always compatible to the common beliefs. The following example concerns the creditability of the viruses' diagnostic tests, is a timely example, due to the current COVID-19 pandemic:

Assume that $2 \%$ of the inhabitants of country have been infected by a dangerous virus. Mr. $X$, who has not any symptoms of the corresponding disease, makes a diagnostic test, the statistical accuracy of which is $97 \%$. The test is positive. Find the probability for Mr. $\mathrm{X}$ to be a carrier of the virus. 
For this, consider the following events $A=$ The subject is a carrier of the virus and $B=$ The test is positive. From the given data it turns out that $P(A)=0.02$ and $P(B / A)=0.97$. Further, among 100 inhabitants of the country, 2 on average are carriers and 98 are not carriers of the virus. Assuming that all those people make the test, we should have on average $2 \times 97 \%=1.94$ positive tests from the carriers and $98 \times 3 \%=2.94$ positive tests from the no carriers of the virus, i.e. 4.88 in total positive tests. Therefore, $P(B)=0.488$. Replacing the values of $P(A), P(B / A)$ and $P(B)$ in equation (2) one finds that $P(A / B) \approx 0.398$. Therefore, the probability for Mr. $X$ to be a carrier of the virus is only $39.8 \%$ and not $97 \%$, as it could be thought through a first, rough estimation!

In general, the sensitivity of the solution is great, depending on the values of the prior probability $\mathrm{P}(\mathrm{A})$. The greater the value of $P(A)$, the higher the creditability of the test.

Closing this section, it is of worth making a reference to the famous accident of the Air France flight AF 447 from Rio de Janeiro to Paris on June 1, 2009, which disappeared during stormy weather over a remote part of the Atlantic carrying 228 passengers and crew to death. The aircraft's wreckage was found two years later, only after applying Bayesian Statistics based on the data of the previous failures to find it [32].

\section{Bayesian Reasoning in Science}

Many scientists and philosophers of science argue today that the whole science could be considered as a Bayesian process [27-29]. Here, we shall attempt to justify theoretically this view. The process of scientific thinking is graphically represented in Figure 2, retrieved from [29]. In that Figure, $a_{1}, a_{2}, \ldots, a_{n}$ are observations of the real world. The attempt to explain and justify those observations has led by induction (intuitively) to the development of theory $T_{1}$. Theory $T_{1}$ was verified by deduction and additional deductive inferences $K_{1}, K_{2}, \ldots ., K_{s}$ were obtained. Next, a new series of observations $b_{1}, b_{2}, \ldots, b_{m}$ followed. If some of those observations are not compatible to the laws of theory $T_{1}$, a new theory $T_{2}$ is developed to replace/extend $T_{1}$, and so on. In each case the new theory extends or rejects the previous one approaching more and more to the absolute truth.

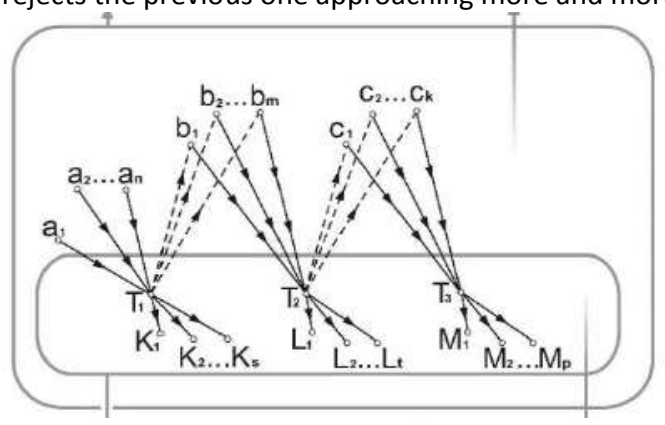

Figure 2. The scientific method

This procedure is known as the scientific method. The term was introduced during the $19^{\text {th }}$ century, when significant terminologies appeared establishing clear boundaries between science and no science. However, the scientific method characterizes the development of science since at least the $17^{\text {th }}$ century. Aristotle is recognized as the inventor of the scientific method due to his refined analysis of the logical implications contained in demonstrative discourse. The first book in the history of human civilization written on the basis of the principles of the scientific method is, according to the existing witnesses, the "Elements" of Euclid (365-300 BC) addressing the axiomatic foundation of Geometry. The scientific method is highly based on the Trial and Error procedure, a term introduced by C. Lloyd Morgan (1852-1936) [33]. The trial and error procedure is characterized by repeated attempts, which are continued until success or until the subject stops trying

For example, the geocenrtic theory (Almagest) of Ptolemy of Alexandria (100-170), being able to predict satisfactorily the movements of the planets and the moon, was considered to be true for centuries. However, it was finally proved to be wrong and has been replaced by the heliocentric theory of Copernicus (1473-1543). The Copernicus' theory was supported and enhanced a hundred years later by the observations/studies of Kepler and Galileo, but it faced many obstacles for a long period, especially from the church, before its final justification [34]. Another characteristic example is the Einstein's general theory of relativity developed at the beginning of the $20^{\text {th }}$ century. This theory has replaced the Newton's classical gravitational theory, which was believed to be true for more than two centuries [35].

The previous discussion reveals the importance of inductive reasoning for scientific thinking. In fact, the premises of all the scientific theories (with possible exception only for pure mathematics), expressed by axioms, basic principles, etc., are based on human intuition and inductive reasoning. Therefore, a deductive inference developed on the basis of a scientific theory, is true under the CONDITION that the premises of the corresponding theory are true. In other words, if $\mathrm{H}$ denotes the arguments imposed by those premises and I denotes the deductive inference, then the conditional probability $\mathrm{P}(\mathrm{I} / \mathrm{H})$, which can be calculated by the Bayes' rule, expresses the degree of truth of the deductive inference. Consequently, the argument that the whole science could be considered as a Bayesian process seems to have a reasonable basis.

It must be emphasized here that the error of the inductive reasoning is transferred to a deductive inference through its premises. Therefore, the scientific error in its final form is actually a deductive and not an inductive error! This means that none of the existing scientific theories could be considered as been absolutely true; it simply could be considered as approaching in a better way the truth than the previous theories that has replaced, did.

\section{Computational Thinking}

Living in the era of information and increasing progress of technology, combining knowledge and technology to solve problems is becoming the mode rather than the exception. Creativity and innovation driven by tacit knowledge, CrT driven by logic and ST based on the rules of Probability and Statistics have become the tools for problem thinking and PS. If technology is added as another tool, however, then CT becomes also a prerequisite. 
Computation is an increasingly essential tool for doing scientific research. It is expected that future generations of scientists and engineers will need to engage and understand computing in order to work effectively with computational systems, technologies and methodologies. CT, in its broader meaning other than performing computations, is a type of analytical thinking that employs mathematical and engineering thinking to understand and solve complex problems within the constraints of the real world. The term was first used by S. Papert [36], who is widely known for the development of the Logo software. However, it was brought to the forefront of the computer society by Wing [37] to describe how to think like a computer scientist. She described CT as "solving problems, designing systems and understanding human behaviour by drawing on the concepts fundamental to computer science".

The main characteristics of $\mathrm{CT}$ include:

- Analyzing and logically organizing data

- Data modelling, data abstractions, and simulations

- Formulating problems such that computers may assist

- Identifying, testing, and implementing possible solutions

- Automating solutions via algorithmic thinking

- Generalizing and applying this process to other problems.

According to Liu and Wang [38], CT is a hybrid of the following modes of thinking:

1.Abstract thinking, which informally can be thought as the mapping from a ground representation to a new, but simpler representation. In solving an interesting problem, abstraction of thinking is one very general purpose heuristic that can help to attack this problem.

2.Logical thinking, a process in which one uses reasoning consistency to come to a conclusion. Some problems or states (situations) involving logical thinking always call for mathematics structure for relationships between some hypotheses and given statements and for a sequence of reasoning that makes the conclusion more reasonable.

3.Modelling thinking, which refers to the translation of objects or phenomena from the real world problem into mathematical equations (mathematical models) or computer relations (simulation models). In this way the corresponding problem becomes tractable.

4.Constructive thinking, which is any well-defined computational procedure that takes some value, or set of values, as input and produces some value, or set of values, as output.

The above components are necessary thinking modes for synthesising $\mathrm{CrT}$ and existing knowledge and applying them to solve the problem. CT does not propose that problems need to be solved in the same way a computer tackles them, but rather encourages $\mathrm{CrT}$ using computer science concepts and techniques. Learning to think computationally or to problem-solve through abstraction is the ability to eliminate details from a given situation in order to find a solution that might not be forthcoming under other circumstances [33].

Voskoglou and Buckley in an earlier work [39] developed a model shedding some light to the relationship between CT and $\mathrm{CrT}$ in PS, which is graphically represented in Figure 3. In this model, the three components of CrT, CT and existing knowledge act simultaneously on the problem at hand. The model is based on the hypothesis that, if there is sufficient background knowledge, the new, necessary for the solution of the problem, knowledge is triggered with the help of CrT; then CT is applied and the problem is solved. It is of worth noting that, on the basis of what it has been already discussed in this paper, ST, in cases where is needed, should join $\mathrm{CrT}$ in this scheme.

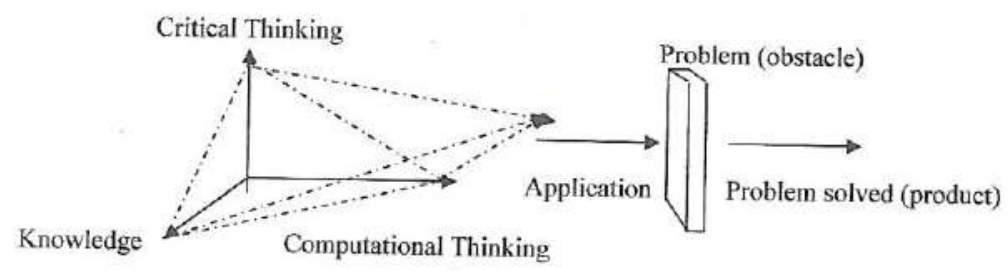

Figure 3. The PS model of Voskoglou and Buckley

Computer Science is not just about programming, it's about an entire way of thinking, which is now an intrinsic part of our lives. One could argue that nowadays a world without computers would be unthinkable. CT is becoming recognized as an important way to educate new generations of students who will become skilled not only at using tools, but also at creating them. All of today's students will go on to live a life heavily influenced by computing, and many will work in fields that involve or are influenced by computing. There is therefore a need to start teaching CT early and often. Recent studies in this field address the necessity to become trained in thinking computationally before learning programming, and conclude that the education of programming along with the theory of computing needs to be represented in a way that would make sense to students within the computer science discipline [40].

In thinking as a computer scientist, researchers become aware of behaviours and reactions that can be captured in algorithms or can be analysed within an algorithmic framework. CT now gives them a different framework for visualizing and analysing, a whole new perspective. To rephrase a common idiom, "until you have a screwdriver, everything looks like a nail." CT develops a variety of skills (logic, creativity, algorithmic thinking, modelling/simulations), involves the use of scientific methodologies and helps developing both inventiveness and innovative thinking. It has roots in mathematics, engineering, technology and science and in the synthesis of ideas from all these fields, has created a way of thinking that is only just beginning to generate enormous changes and benefits. 


\section{CONCLUSION}

The discussion performed in this paper leads to the following conclusions:

- PS is a complex cognitive process that needs the combination of several modes of thinking in order to be successful. Those modes, apart from the simple spontaneous thinking, include CrT, ST and CT.

- Probability and Statistics are related areas of mathematics, having however fundamental differences. Probability deals with predicting the likelihood of future events, whereas Statistics tries to make sense of observations in the real world by analyzing the frequency of past events.

- The cultivation of ST is very important for PS, because enables one to combine harmonically principles of Probability and Statistics for solving problems with uncertain outcomes characterized by randomness. However, ST should be always combined with $\mathrm{CrT}$.

- Methods of FL are usually applied today for tackling the problems of uncertainty due to imprecision of the given data. Bayesian Reasoning, however, where the outcomes change by considering all the possible values of the prior probability, could be seen as an interface between bivalent and FL for tackling such kind of problem.

\section{References}

1. Schoenfeld, A. (1983), The wild, wild, wild, wild world of problem solving: A review of sorts, For the Learning of Mathematics, 3, 40-47.

2. Polya, G. (1973), How I solve it: A new aspect of mathematical method, New Jersey: Princeton University Press.

3. Green, A. J. K. \& Gillhooly, K. (2005), Problem solving, in Braisby, N. \& Gelatly, A. (Eds.), Cognitive Psychology, Oxford University Press, Oxford.

4. Martinez, M. (2007), What is meta cognition? Teachers intuitively recognize the importance of metacognition, but may not be aware of its many dimensions, Phi Delta Kappan, 87(9), 696-714.

5. Halpern, D. (2003), Thought and knowledge: An introduction to critical thinking, $4^{\text {th }}$ edition, Mahwah, Earlbaum, NJ, USA.

6. Mc Guinness, C. (1993), Teaching thinking: New signs for theories of cognition, Educational Psychology, 13(3-4), 305-316.

7. Williams, R. L. (2005), Targeting critical thinking within teacher education: The potential impact on Society, The Teacher Educator, 40(3), 163-187.

8. Mc Peck, J. E. (1981), Critical thinking and education, Martin Robinson, Oxford.

9. Brookfield, S.D. (1987), Developing critical thinkers: Challenging adults to explore alternative ways of thinking and acting, Open University Press, England.

10. Pascarella, E. T. \& Terenzini, P. (1991), How college affects students, Jossey-Bass, San Francisco.

11. Martinez, M. (2007), What is metacognition? Teachers intuitively recognize the importance of metacognition, but may not be aware of its many dimensions", Phi Delta Kappan, 87(9), 696-714.

12. Tiwari, A., Lai, P., So, M. \& Yuen, K. (2006), A comparison of the effects of problem-based learning and lecturing on the development of students' critical thinking, Med. Educ.,41(2), 156-174.

13. Jaynes, E.T. (2011), Probability Theory: The Logic of Science, $8^{\text {th }}$ Printing, Cambridge University Press, UK.

14. Mumford, D. (2000), The Dawning of the Age of Stochasticity, in V. Amoid, M. Atiyah, P. Laxand \& B. Mazur (Eds.), Mathematics: Frontiers and Perspectives, AMS, 197-218.

15. Kosko, B. (1993), Fuzzy Thinking: The New Science of Fuzzy Logic, Hyperion, NY, USA.

16. Zadeh, L.A. (1965), Fuzzy Sets, Information and Control, 8, 338-353.

17. Voskoglou, M.Gr. (2019), Methods for Assessing Human-Machine Performance under Fuzzy Conditions, Mathematics, 7, article 230.

18. Changingminds.org, Full alphabetic list of Fallacies, available online: http://changingminds.org /disciplines/argument/fallacies/fallacies_alpha.htm (accessed on 23 June 2020).

19. Athanassopoulos, E. \& Voskoglou, M.Gr. (2020), Quantifying the Aristotle's Fallacies, Mathematics, 8, article 1399.

20. Gardener, J. \& Resnik, D. (2002), The misuse of statistics, concepts, tools and a research agenda, Accountability in Research: Policies and Quality Assurance, 9(2), 65-74.

21. Wason, P. C. (1977), Self-contradictions, in Johnson-Laird, P. N.; Wason, P. C. (Eds.), Thinking: Readings in cognitive science, Cambridge, Cambridge University Press.

22. Evans, J.St.B.T., Newstead, S. E., Byrne, R.M.J. (1993), Human Reasoning: The Psychology of Deduction, Psychology Press, East Sussex, UK.

23. Tversky, A., \& Kahneman, D. (1982), Judgment under uncertainty: Heuristics and biases, Cambridge University Press, Cambridge, UK.

24. Gould, S. J. (1992), Bully for brontosaurus: Reflections in natural history, Norton, New York.

25. Aristidou, M. (2013), Irrationality Re-Examined: A Few Comments on the Conjunction Fallacy, Open Journal of Philosophy, $3(2), 329-336$.

26. Schuler, J. \& Lipschutz, S. ((2010), Schaum's Outline of Probability, $2^{\text {nd }}$ Edition, McGraw Hill, NY.

27. Horgan, J. (2015), Bayes' Theorem: What is the Big Deal?", available in http//:blogs. scientificamerican.com /cross-check/ bayes-s-theorem-what-s-the-big-deal.

28. Bertsch McGrayne, S. (2012), The Theory that would not die, Yale University Press, New Haven and London.

29. Athanassopoulos, E. \& Voskoglou, M.Gr. (2020), A Philosophical Treatise on the Connection of Scientific Reasoning with Fuzzy Logic, Mathematics, 8, article 875.

30. What do you think about machines that think? (2015), available in http://edge.org/response-detail/26871.

31. Jeffreys, H. (1973), Scientific Inference, 3d Edition, Cambridge University Press, UK, 1973. 
32. Stone, L.D., Keller, C.M., Kratzke, T.M. \& Strumpfer, J.F. (2014), Search for the Wreckage of the Air France Flight AF 447, Statistical Science, 29(1), 69-80.

33. Thrope, W.H (1979), The origins and rise of ethology: The science of the natural behavior of animals, Praeger, London-NY.

34. Gingerich, O. (1993), The Eye of the Heaven - Ptolemy, Copernicus, Kepler, American Institute of Physics, NY, USA.

35. Singh, S. (2005), Bing Bang - The Origin of the Universe, Harper Perennian Publishers, NY, USA.

36. Papert, S. (1996), An exploration in the space of Mathematics Education, International Journal of Computers for Mathematics, $1(1), 95-123$.

37. Wing, J. M. (2006), Computational thinking, Communications of the ACM, Vol.49, 33-35.

38. Liu, J. \& Wang, L. (2010), Computational Thinking in Discrete Mathematics, IEEE $2^{\text {nd }}$ International Workshop on Education Technology and Computer Science, 413-416.

39. Voskoglou, M. Gr. \& Buckley, S. (2012), Problem Solving and Computers in a Learning Environment, Egyptian Computer Science Journal, 36(4), 28-46.

40. Kazimoglu, C., Kiernan, M., Bacon, L. \& MacKinnon, L. (2011), Understanding Computational Thinking Before Programming: Developing Guidelines for the Design of Games to Learn Introductory Programming Through Game-Play, International Journal of Game-Based Learning, 1(3), 30-52.

\title{
СПОСОБИ МИСЛЕННЯ ПРИ ВИРІШЕННІ ПРОБЛЕМ
}

\author{
Майкл Г. Воскоглу
}

Вищий технологічний освітній інститут західної Греції, Греція

Анотація.

Постановка проблеми. Вирішення проблем впливає на наше повсякденне життя прямим чи опосередкованим чином протягом століть. Способи мислення, що використовуються при вирішенні проблем, є актуальним предметом дослідження.

Матеріали та методи. Використані методи аналізу засновані на синтезі вже відомих досліджень та відповідних прикладів, що ілюструють наші результати.

Результати. У статті вивчається роль статистичного мислення при вирішенні проблем, де проблема сприймається у широкому розумінні (не лише математичні проблеми). Особливий наголос приділяється Байєсовому мисленню, значення якого у повсякденному житті та науці застосовується повністю лише нещодавно. Також обговорюються інші два основні способи мислення, що використовуються при вирішенні проблем, - критичне та обчислювальне мислення.

Висновки. Вирішення проблем - це складний пізнавальний процес, який для досягнення успіху обумовлює інтегроване використання кількох способів мислення. Ці способи, крім простого спонтанного мислення, включають критичне, статистичне та обчислювальне мислення.

Ключові слова: вирішення проблеми, критичне мислення, статистичне мислення, обчислювальне мислення, байєсівське міркування, нечітка логіка. 